\title{
Performance Enhancement of Photovoltaic Panel Using Double- sides Water Glazing Chambers Cooling Technique
}

\author{
Farag Mahel Mohammed ${ }^{1}$, Jamal Abdul-Kareem Mohammed ${ }^{2}$, Mustafa Abdul-Sayed Sanad ${ }^{3 *}$
}

\section{Authors affiliations: \\ 1) Dep. of Electromechanical Engineering, University of Technology, Baghdad- Iraq drfaragmahel@yahoo.com}

2) Dep. of Electromechanical Engineering, University of Technology, Baghdad- Iraq 50128@,uotechnology.edu.iq

$\left.3^{*}\right)$ Dep. of Electromechanical Engineering, University of Technology, Baghdad- Iraq mustafairaq61@yahoo.com

\section{Paper History:}

Received: $12^{\text {th }}$ Sep. 2018

Revised: $21^{\text {th }}$ Nov. 2018

Accepted: 18 $8^{\text {th }}$ March. 2019

\begin{abstract}
The efficiency of the solar PV panel decreases significantly as the PV panel's operating temperature increases. There are many cooling techniques might be suitably deal with this problem to enhance the solar panel efficiency. The presented cooling technique used for solving the PV panel's temperature elevation is an active close loop cooling system, accomplished using two water glazing chambers made from acrylic glass placed at the PV panel surfaces (rear and front). These champers are utilized for cooling down the PV cell's temperature, as well as filtering the useful sunlight spectrum. The results show that the PV cell's temperature reduction by $50.06 \%$ with using the cooling system, this leads to an average increase in the maximum output power and consequently electrical efficiency of the PV panel by about $12.69 \%$ and $14.2 \%$, respectively.
\end{abstract}

Keywords: Solar PV Panel, Cooling Technique, Glazing Chamber, Efficiency

$$
\begin{aligned}
& \text { تحسين أداء اللوح الشمسي باستخدام تقنية التبريد ثنائي الجوانب بالغرف المزججة }
\end{aligned}
$$

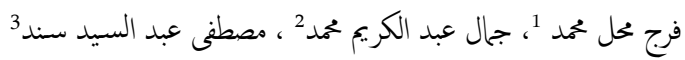

$$
\begin{aligned}
& \text { الخلاصة: } \\
& \text { تنخفض كفاءة الألواح الكهروضوئية الشمسية بشكل كير مع زيادة درجة حرارة تشغيل اللوح الكهروضوئي. }
\end{aligned}
$$

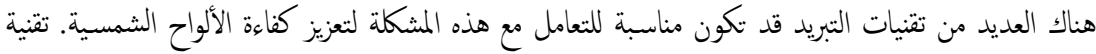

$$
\begin{aligned}
& \text { التبريد المقترحة والمستخدمة لحل ارتفاع درجة حرارة اللوح الشمسي هي نظام تبريد حلقة مغلقة نشطة ، ينات فيتم إنجازها }
\end{aligned}
$$

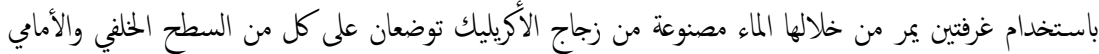

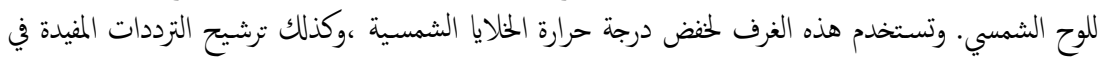

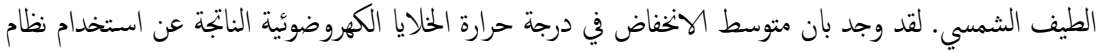

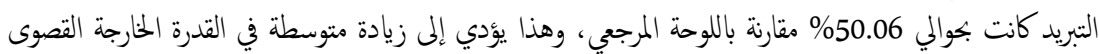

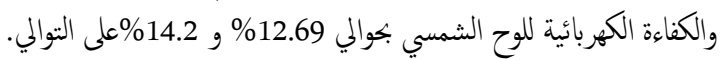

\section{Nomenclature}

$\mathrm{A}_{\mathrm{c}} \quad$ Cross-sectional area for inlet fluid $\left(\mathrm{m}^{2}\right)$

$A_{s} \quad$ Total surface area for heat transfer $\left(\mathrm{m}^{2}\right)$

c Cross sectional width $(\mathrm{m})$

$\mathrm{c}_{\mathrm{p}} \quad$ Specific heat $(\mathrm{J} / \mathrm{kg} \mathrm{k})$

$\mathrm{d} \quad$ Cross sectional high (m)

$\mathrm{D}_{\mathrm{h}} \quad$ Hydraulic diameter $(\mathrm{m})$

h Convection heat-transfer coeff. (W/ $\mathrm{m}^{2} \mathrm{~K}$ )

$\mathrm{m}^{*} \quad$ Mass flow rate $(\mathrm{Kg} / \mathrm{s})$

$\mathrm{N}_{\mathrm{u}} \quad$ Nusselt number

$\mathrm{P}_{\mathrm{m}} \quad$ Maximum Power (W)

$P_{r} \quad$ Prandtl number

$\mathrm{q}_{\mathrm{c}} \quad$ Convection heat transfer (W)

$\mathrm{R}_{\mathrm{e}} \quad$ Reynolds number

$\mathrm{T}_{\mathrm{e}} \quad$ Fluid exit temperature $(\mathrm{K})$

$\mathrm{T}_{\mathrm{i}} \quad$ Fluid inlet temperature $(\mathrm{K})$

$\mathrm{T}_{\mathrm{m}} \quad$ Fluid (or bulk) temperature $(\mathrm{K})$

$\mathrm{T}_{\mathrm{w}} \quad$ Surface temperature $(\mathrm{K})$

$\begin{array}{ll}v & \text { Fluid velocity }(\mathrm{m} / \mathrm{s}) \\ \mathrm{V}_{\mathrm{mp}} & \text { Maximum voltage }(\mathrm{V}) \\ \mathrm{V}_{\mathrm{oc}} & \text { Open circuit voltage }(\mathrm{V}) \\ \mathrm{V}_{\text {out }} & \text { Light sensor output voltage }(\mathrm{V}) \\ \eta_{\text {elec }} & \text { PV panel electrical efficiency } \% \\ \mu & \text { Dynamic viscosity }(\mathrm{kg} / \mathrm{m} \mathrm{s}) \\ \varrho & \text { Fluid density }\left(\mathrm{Kg} / \mathrm{m}^{3}\right)\end{array}$

\section{1-Introduction:}

Solar energy is the available renewable energy source. This energy is clean and easily available. The solar technologies employ the sun to provide heat, light, electricity, etc. for domestic and industrial applications. The use of solar energy reduces the harmful environmental effects resulting from burning of fuel used in power generation plants, as well as house gases and other air impurity emissions. One of the techniques that invest this energy is the

NJES is an open access Journal with ISSN 2521-9154 and eISSN 2521-9162

This work is licensed under a Creative Commons Attribution-NonCommercial 4.0 International License 
Photovoltaic (PV) cells. At present, scientists consider that PV technology is the most realistic tool to offset the growing energy requirements of the future. PV solar cells turn sunlight directly into electricity which lead to increase the demand for solar cells. Almost, more than $80 \%$ of the energy is got from fossil fuels [1].

The PV cells are receiving about $80 \%$ of the solar irradiance falling on their surface, but only a little part of the incident irradiance is harnessed for electrical usage depending on the electrical efficiency of the PV cells [2]. The rest of energy will be dissipated as a heat causes an increment in the PV module temperature which might reach $40^{\circ} \mathrm{C}$ above the ambient [3]. It is found, for crystalline silicon PV cells that the electrical output power drops by $(0.2-0.5) \%$ for each rise of $1{ }^{\circ} \mathrm{C}$ in the PV module temperature. Because the temperature dependence on the open-circuit voltage of the PV cell and the PV technology [4]. The P/V characteristic represents the relation between the electrical output power of the solar cells and the output voltage at constant solar irradiance for certain module temperature. The maximum power output of the solar cells reduces when the cell temperature increases [5]. Therefore, it is necessary to keep the PV panel at lower temperature as possible.

There are many researches are dealing with the PV cooling systems. Krauter [6] suggested a cooling method for the PV panel by reducing the sunlight reflection via replacing the original front PV glass layer of the PV panel with $1 \mathrm{~mm}$ thin layer attached directly the front surface of the panel cells. The study achieved a net-gain of electrical power of $8-9 \%$. Abdolzadeh and Ameri [7] investigated the performance of the water pumping system needed to cool the PV module by using water sprayer technique over the front surface of the PV panel. The result showed that the PV cell efficiency was increased by $3.26 \%$. Hosseini et al. [8] carried out a cooling technique consisting of a water thin film passing over the top of the PV panel's surface using water sprayer technique. This technique lead to improve the peak output efficiency by $26 \%$. Teo et al. [9] implemented an active cooling system for cooling the PV module. Ducts arranged in parallel with inlet and outlet channels were designed to create a uniform distribution of air flow. The results showed that the module temperature attained up to $68 \mathrm{oC}$ resulting a drop in the electrical efficiency by $8.6 \%$. Bahaidarah et al. [10] studied the PV panel's performance using a heat exchanger as a coolant device touching the rear surface of the PV module as a cooling tool. The result showed that the PV module temperature was significantly dropped to $20 \%$, leading to increase the efficiency by $9 \%$. Colt [11] enhanced the performance of a PV panel by using an active water-cooling technique as a radiator mounted on the rear surface of the PV panel. The module temperature reduced significantly by about $32 \%$ with range of $(50-34 \mathrm{oC})$. This leads to raise the electrical panel efficiency by $57 \%$ ranged with $(7-11 \mathrm{~W})$. Ali [12] enhanced the PV panel performance by designing and implementing a cooling system based on water flow double glazing (WFDG) cooling technique for cooling the front surface of the PV module's panel in close loop cooling system, where the water passing through a heat exchanger burred underground to cool the water. Taguchi method was used work as an optimization way to estimate the better water mass flow rate and thickness necessary to design the (WFDG) cooling system. The average reduction of the PV temperature resulting from the cooling system was 35\% causing an average increase of the electrical efficiency by $(16 \%)$. Abu-Rahmeh[13] presented an experimental investigation of the efficiency of a photovoltaic module using three different cooling methods. The first and second method is the PV modules are cooled using water and a nanofluid, respectively, flowing inside copper tubes. The third method used was the PV module is cooled by using 24 vertical Aluminum rectangular fins. It was concluded that the electricity yield of the PV module cooled by $0.04 \%$ wt $\mathrm{TiO} 2$ nanofluid, water and fins compared with uncooled PV was higher by $5.37 \%, 2.62 \%$ and $1.34 \%$, respectively. Satpute and Rajan [14] reviewed a various cooling technique used to enhance cooling and electrical performance. The study was focus on the operating parameters like absorber configuration, flow pattern, flow rates, climatic conditions, radiation intensity, wind speed, thermal conductivity, and glazing, concentration on the electrical and thermal characteristics. The results show that the Performance of PVT system mainly depends on the variables like incident solar radiation, wind speed, ambient temperature, geometry of collector and heat transfer fluid.

The present study aims to improve the cooling technique by cooling the rear and front sides of the PV panel surfaces. As well as, the chambers' layers that touching the rear and front PV panel surfaces are removed to make the water in direct contact with the PV panel surfaces.

\section{2-Water Flow Glazing Chamber Technique:}

The Glazing, is usually known as double glazing or (double-pane) and increasingly or triple glass window panes that separated by vacuum or gas filled space to decrease heat transfer through a section of a building envelope. Recently, glazing windows are widely used in the advanced building facades that use day lighting, ventilation systems, sun control, and dynamic systems [15]. The incoming solar energy falling on these windows is not invested in such designs, even where the glazing is electrochromic. In order to overcome this problem, a Water Flow Glazing (WFG) system had been proposed by Chow [16]. The WFG systems were used in buildings to reduce the space cooling load, at the same time, utilize the solar radiation as an energy source. The most interesting application of the WFG systems is their use in exteriors such as facades, skylights, curtain walls, and rooftops. The special characteristics of this system can be fully invested, in order to reduce the energy consumption. Because of those advantages, the WFG technique was invested by [12] for cooling the solar PV module. In the present work, some suitable modifications are accomplished to make more enhancement on the PV module efficiency where the WFG is built on the PV panel surfaces with 
only five surfaces where the sixth lower layer facing the PV panel surface is removed to make direct contact (no barrier) between the chamber water and the PV surfaces and the water is confined through them. This modification on the WFG is very useful to increase the cooling performance of the PV module.

\section{Mathematical Modeling of the Cooling Chamber:}

According to the technology used for cooling the solar PV panel cells, mathematical calculations will be subjected to the internal forced convection heat transfer laws.

The main law of convection heat transfer, Newton's law of cooling [17], is:

$$
q=h A_{s}\left(T_{w}-T_{m}\right)
$$

Here the heat-transfer rate is related to the overall temperature difference between the wall and fluid and the surface area AS.

The second low of energy balance [17] is:

$$
q=m^{*} C_{p}\left(T_{e}-T_{o}\right)
$$

The first step is determining the Reynolds number (R_e) to specify the type of flow either laminar or turbulent, where the Reynolds number [17] is:

$$
R_{e}=\frac{\rho v D_{h}}{\mu}
$$

Where (D_h) is the hydraulic diameter of the cross-sectional area of the channel. In the presented case, the water stream channel of cooling chamber is square cross-sectional area, the equivalent diameter should be determined. The hydraulic diameter of the square cross-sectional area is given as [17]:

$$
D_{h}=\frac{4 A_{c}}{2(c+d)}
$$
[17]:

The velocity of the fluid $\mathrm{v}$ can be calculated as

$$
m^{*}=\rho v A_{c}
$$

After determining the Reynolds number, the Nusselt number should be calculated as [17]:

$$
N_{u}=0.664 R_{e}^{0.5} P_{r}^{n}
$$

Where, $\mathrm{n}=0.4$ for heated fluid.

The heat transfer coefficient (h) can be obtained directly from the relation of Nusselt number [17]:

$$
N_{u}=\frac{h D_{h}}{k}
$$

Finally, the overall heat transfer rate can be determined by substitution the heat transfer coefficient in Eq. 1, also the difference in temperature (T_w-T_m) can be substituted as it is, in which the heat transfer case is constant heat flux.

\section{4- Experimental Setup:}

The proposed cooling system shown in Fig. 1 is consisting from five main components that are:
1- Two Water glazing chambers (WGCs), upper and lower

2- Water tank and water pump motor

3- Heat exchanger

4- Temperature sensor

5- Inlet and outlet water flexible tubes.

The proposed cooling technique was implemented by mounting two water glazing chamber units in direct contact with both sides of the PV panel, the front and rear surfaces. When the cold water passes through the two chambers, it comes in touch with the panel surfaces. The cooling chamber is made from acrylic panes glass sheets of $2 \mathrm{~mm}$ thick. The acrylic glass has a coefficient of reflection less than most types of ordinary glass, so it reflects less light. Less reflection means more light might pass through it. It has 50\% weight less than ordinary glass. The total light transmitted through the acrylic measured experimentally and found reach to $98.86 \%$.

The thermal design of water-cooling chambers was investigated according to the equations of heat transfer theory mentioned in Sec. 3. The water in those chambers is flowing through the streamline with a laminar flow. The shapes of the cooling chambers depending on the thermal design are illustrate in Figs. 2 and 3. The figures show that the chamber has water inlet and outlet channels such that the water entering the chamber in narrow individual paths. Those paths are separated by parallel acrylic barriers, across the PV panel surface to ensure a uniform path of water stream lines to give better heat extraction. The Arced shape barriers shown on the panel ends are used in round of the path to enhance the water flow in this area. The rear surface cooling chamber is constructed to execute just the cooling task, while the front surface cooling chamber is constructed to execute two tasks, simultaneously. Firstly, it works as an additional watercooling system. Secondly, works as an optical filter based on absorbing the most IR radiation and filtering out by water inside.

When the solar radiation falls on the optical filter, IR component gets absorbed and filtered by the water, and then falls on the crystalline PV cell. The remaining UV and VIS light are transmitted and converted into electricity by the PV solar cell as illustrated in Fig. 4, when the water is completely transparent to VIS light and near-UV. This arrangement also prevents the excessive heating of the solar cells.

The thin water layer is circulated from the cooling chamber to the heat exchanger through the water pump motor, where the hot water exit from the cooling chamber through its outlet flexible tube and collected at the water tank. The water pump motor is pumping the hot water from the water tank to the heat exchanger device. The used heat exchanger acts as a twisted tube buried by about $(1 \mathrm{~m})$ underground where the heat of the water coming from the water tank is discharged throughout its surface to the cold soil. The cooled water, then inlet to the cooling chamber through their inlets flexible tubes for cooling the PV panel. 


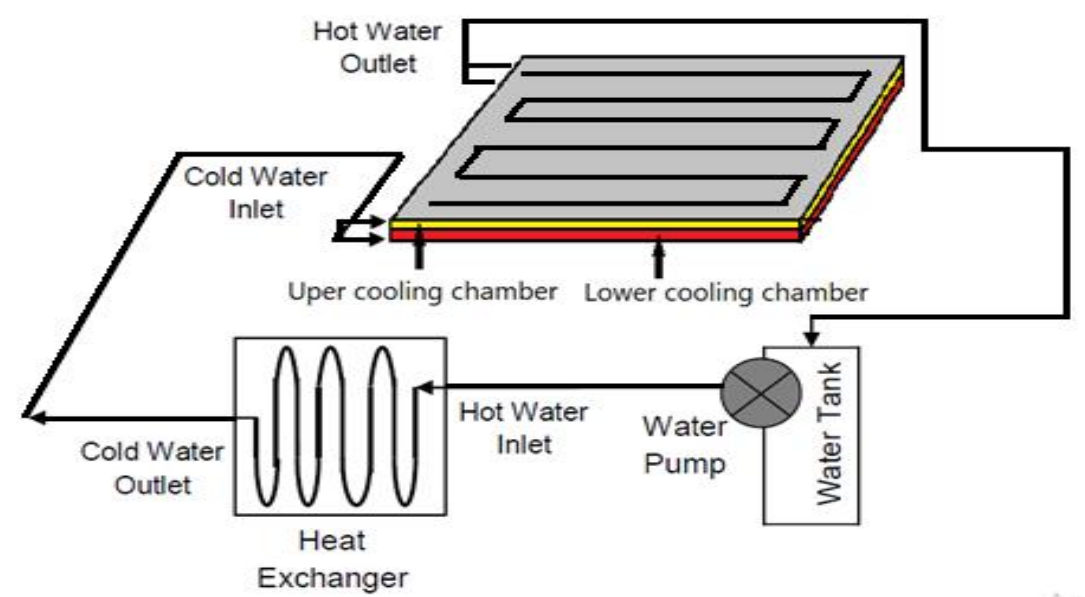

Figure (1): Schematic diagram of the cooling system

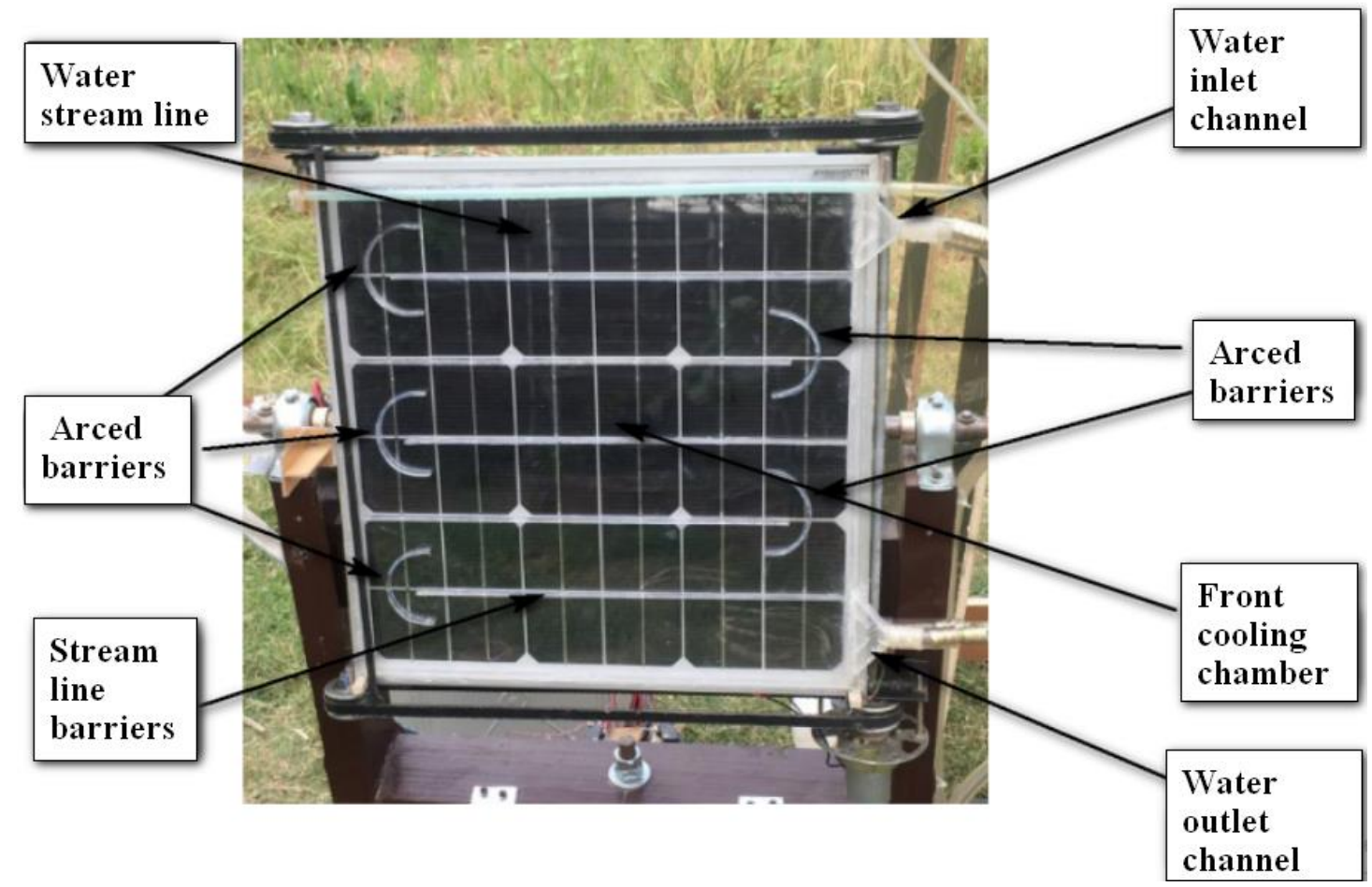

Figure (2): Front cooling chamber

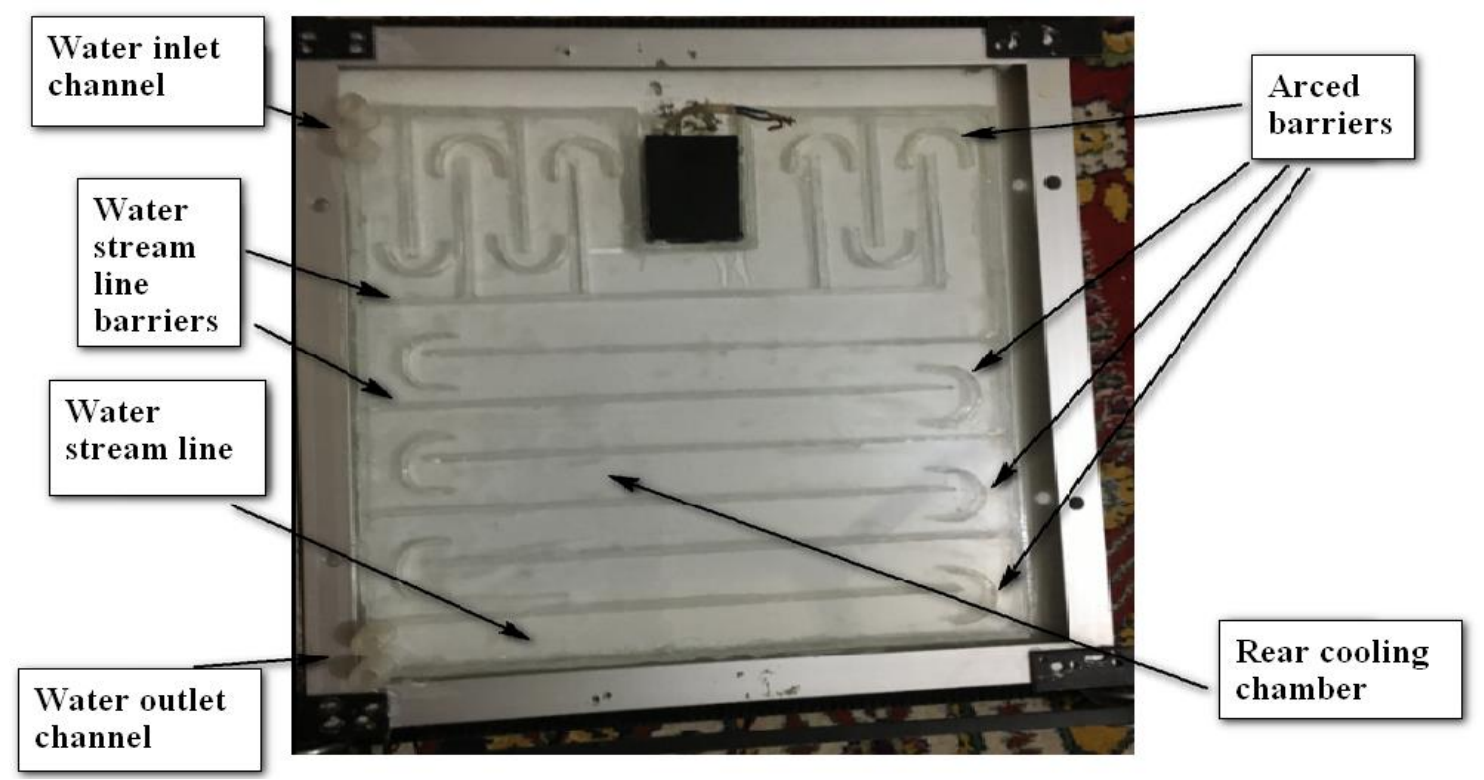

Figure (3): Rear cooling chamber 


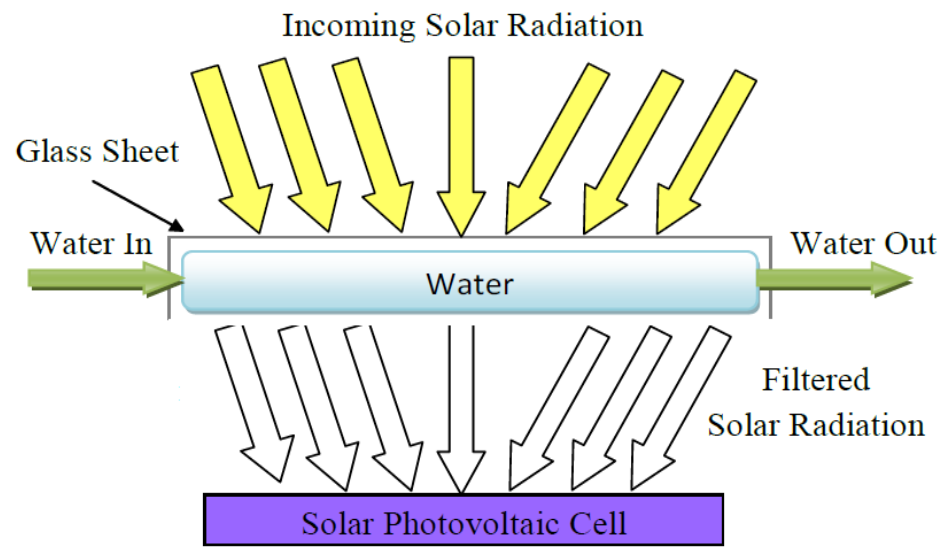

Figure (3): Front cooling system working as an optical filter

\section{5- Results and Discussions:}

The cooling chambers designed according to the parameters results using Eqs. (1-7). The design parameters are $(0.41 \mathrm{~cm}$ layer thickness with $0.032 \mathrm{Kg} / \mathrm{s}$ mass flow rate for rear cooling chamber, and $0.5 \mathrm{~cm}$ thickness with $0.04 \mathrm{Kg} / \mathrm{s}$ mass flow rate for front cooling chamber). The effective solar panel surface area is $0.1806 \mathrm{~m} 2$. The solar PV panel system specifications are listed in Table 1. The experimental results during daytime of three days symmetrical in climate conditions that 10th July, 2nd August and 17th August in 2017 presented in Table 2, for three cases of (front cooling chamber, rear cooling chamber and both front and rear cooling chambers).

Table 1: PV panel and WFDG system specifications

\begin{tabular}{|c|c|c|c|}
\hline \multicolumn{2}{|c|}{ Solar PV panel specifications } & \multicolumn{2}{|c|}{ WFDG system specification } \\
\hline Parameter & Value & Parameter & Value \\
\hline Type & Mono-Si & \multicolumn{2}{|c|}{ Glazing chamber } \\
\hline Rated max. power, $\mathrm{P}_{\max }$ & $20 \mathrm{~W}$ & $\begin{array}{l}\text { Chambers } \\
\text { dimensions }\end{array}$ & $\begin{array}{l}\text { front chamber }(43 \times 42 \times 0.5) \mathrm{cm} \\
\text { rear chamber }(43 \times 42 \times 0.41) \mathrm{cm}\end{array}$ \\
\hline Operating voltage, $V_{\mathrm{mp}}$ & $17.6 \mathrm{~V}$ & Material & Acrylic glass \\
\hline Operating current, $\mathrm{I}_{\mathrm{mp}}$ & $1.14 \mathrm{~A}$ & No. of sheets & Two sheets \\
\hline Open-circuit voltage, $V_{O C}$ & $21.8 \mathrm{~V}$ & Sheet thickness & $2 \mathrm{~mm}$ \\
\hline Short-circuit current, I $\mathrm{I}_{\mathrm{SC}}$ & $1.78 \mathrm{~A}$ & $\begin{array}{l}\text { Thermal } \\
\text { conductivity }\end{array}$ & $0.2 \mathrm{~W} / \mathrm{m} \cdot{ }^{\circ} \mathrm{C}$ \\
\hline Electric efficiency, $\eta_{\text {elec }}$ & $11 \%$ & $\begin{array}{l}\text { Weight of } \\
\text { Chambers }\end{array}$ & $0.8 \mathrm{~kg}$ \\
\hline Weight & $2.5 \mathrm{~kg}$ & \multicolumn{2}{|c|}{ Heat exchanger } \\
\hline Dimensions & $(43 \times 42 \times 2.4) \mathrm{cm}$ & Type & $\begin{array}{c}\text { Finned U tube air cooled } \\
\text { without fan installation frame }\end{array}$ \\
\hline No. of cells & 36 & Material & Copper pipes \\
\hline \multicolumn{2}{|c|}{ Standard Test Conditions, STC } & Aluminum foil & Hydrophilic or bare \\
\hline Air Mass & AM1.5 & Fines & Flat \\
\hline Cell Temperature, Tc & $25^{\circ} \mathrm{C}$ & Dimensions & $(25 \times 25 \times 8) \mathrm{cm}$ \\
\hline Solar Irradiance, Gs & $1000 \mathrm{~W} / \mathrm{m}^{2}$ & $\begin{array}{l}\text { Pipes external } \\
\text { diameter }\end{array}$ & $1 \mathrm{~cm}$ \\
\hline
\end{tabular}

Table 2: Specifications and accuracies of measurement devices

\begin{tabular}{|c|c|c|c|}
\hline Items & Model & Ranges & Accuracy \\
\hline & & - DCV: $400 \mathrm{~m} / 4 / 40 / 400 / 1000 \mathrm{~V}$ & $\pm 0.5 \%$ \\
& & - ACV: $4 / 40 / 400 / 750 \mathrm{~V}$ & $\pm 0.8 \%$ \\
Digital Multimeter & \multirow{2}{*}{ VC97 } & - DCA: $0.4 \mathrm{~m} / 4 \mathrm{~m} / 40 \mathrm{~m} / 400 \mathrm{~m} / 10 \mathrm{~A}$ & $\pm 1.0-1.2 \%$ \\
& & - ACA: $0.4 \mathrm{~m} / 4 \mathrm{~m} / 40 \mathrm{~m} / 400 \mathrm{~m} / 10 \mathrm{~A}$ & $\pm 1.5-2 \%$ \\
& & - Temperature: $-20 \sim 1000{ }^{\circ} \mathrm{C}$ & $\pm 1 \%$ \\
& & - FREQ: $100 \mathrm{~Hz} \sim 30 \mathrm{MHz}$ & $\pm 0.5 \%$ \\
\hline Digital thermometer & DM6802A & Temperatures range: $-50 \sim 1300{ }^{\circ} \mathrm{C}$ & $\pm 1{ }^{\circ} \mathrm{C}$ \\
\hline Solar power meter & SPM-1116SD & Irradiance range: $(0-2000) \mathrm{W} / \mathrm{m}^{2}$ & $\pm 10 \mathrm{~W} / \mathrm{m}^{2}$ \\
\hline
\end{tabular}

\subsection{Front cooling chamber:}

The distribution of solar irradiance during the daytime is shown in Fig.5. The irradiance is ranged between (540-901) W/m2. The sun rays will be absorbed by the acrylic sheet and other will pass across the sheet for useful energy transformation. It can notice that using the layer sheet for the front cooling 
chamber will not has significant impact on the irradiance level.

Fig.6 present the ambient temperature and the corresponding PV panel temperature distribution during the daytime. The results show that the PV temperature averagely reduce by $45.56 \%$ with using front cooling chamber as compared with reference panel. Fig.7 show the PV panel output power distribution during daytime. The maximum power increment reaches to $15.95 \%$ takes at 2:00 PM. While, the average power increment is $11.66 \%$. Fig. 8 illustrates the electrical efficiency of the solar panel. The results show with using front cooling technique, the maximum value of increment in the electrical efficiency is $18.39 \%$ at 2:00 PM.

The results show a good agreement as compared with the results of Ali [12], that use also the front cooling technique. So, the modification proposed in this work by adding the rear cooling technique.

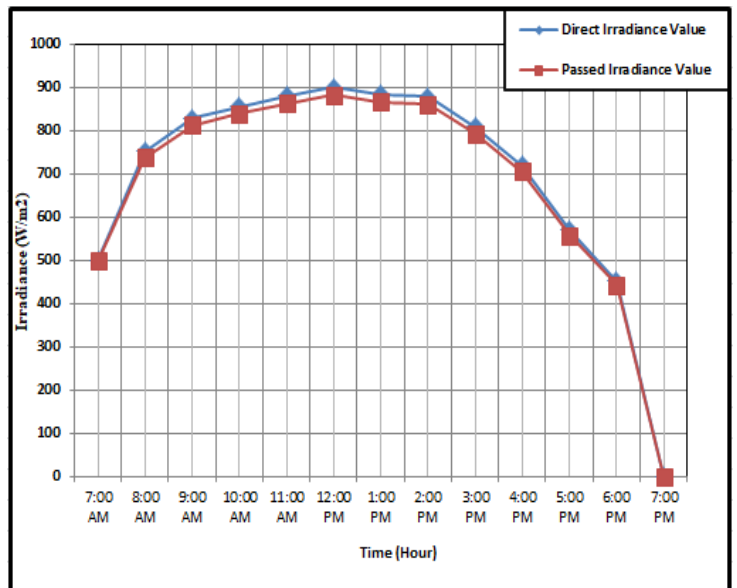

Figure (5): Solar irradiance distribution for two cases (passed and direct) during daytime

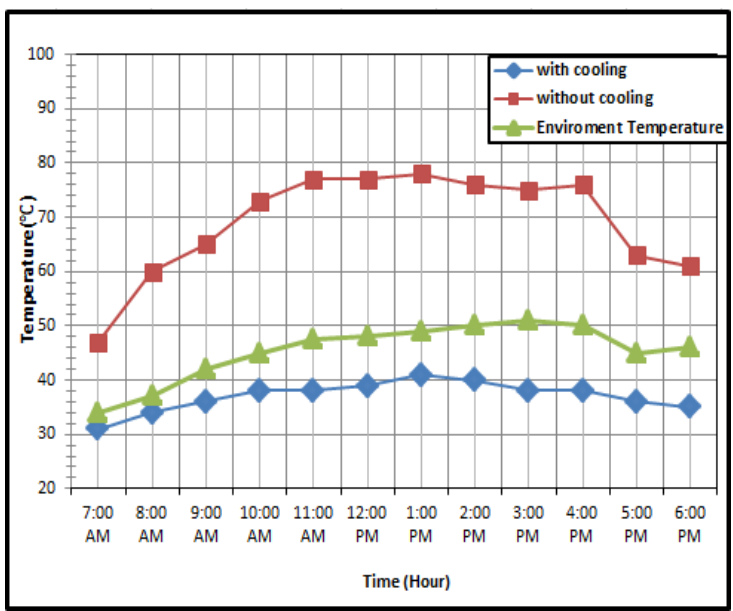

Figure (6): PV panel and environment temp. during daytime (front cooling)

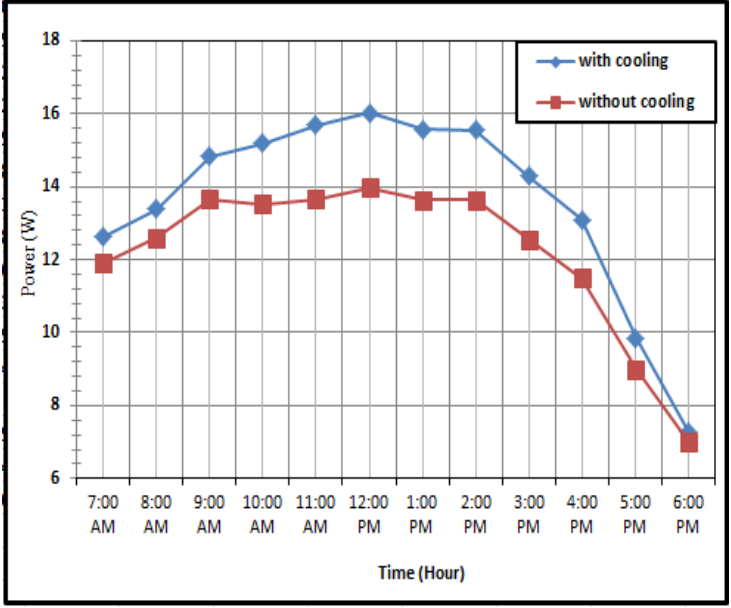

Figure (7): Output power during daytime (front cooling)

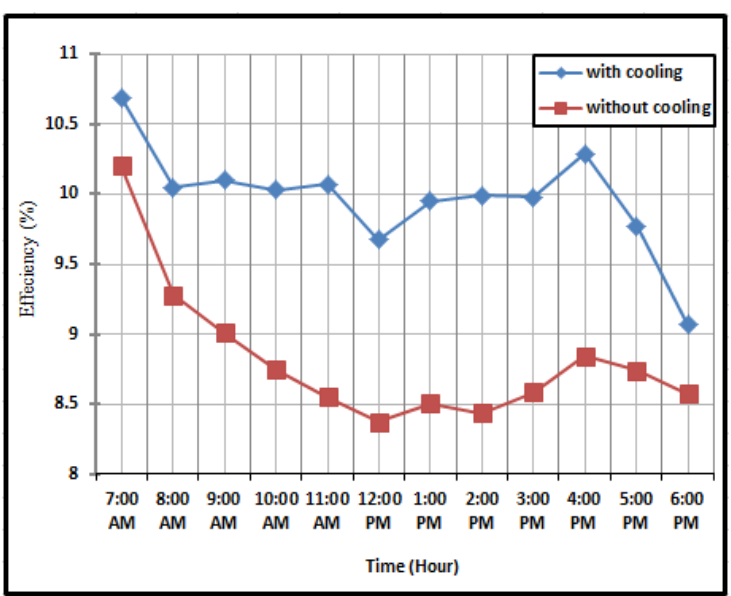

Figure (8): Panel efficiency during daytime (front cooling)

\subsection{Rear cooling chamber:}

The environment temperature measured was ranged between (33-50) oC, while the PV panel surface temperature between (50-78) oC at irradiance range of (492-895) W/m2 as shown in Figs. 9 and 10. The results show that the rear cooling technique causes a reduction in the panel temperature averagely by $(40.12 \%)$. While Fig. 11 represent the maximum output power distribution during daytime with using rear cooling technique. The maximum power is being limited at the time interval of (10:00 AM -3:00 PM). The maximum power increment reaches to $14.48 \%$ at 1:00 PM. While the average power with and without using rear cooling chamber is $12.47 \mathrm{~W}$ and $13.64 \mathrm{~W}$ respectively. This leads to an average increment of $9.38 \%$.

Fig. 12 show the effect of using rear cooling chamber on the PV panel electrical efficiency behavior during the daytime. The results show that with using rear cooling technique, the maximum increment in the efficiency is $14.52 \%$ at $1: 00 \mathrm{PM}$ as compared with that of no cooling case. The average electrical efficiency of the PV panel without and with using rear cooling technique is $9.17 \%$ and $10 \%$, respectively. 


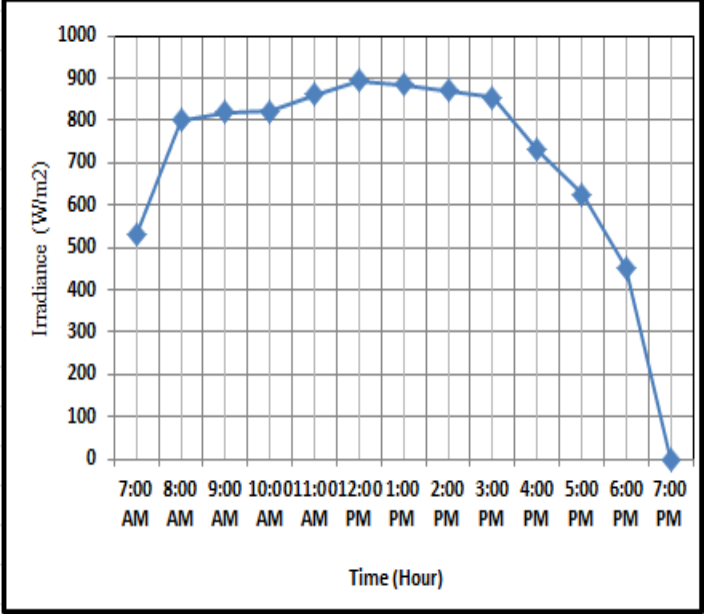

Figure (9): Solar irradiance during daytime (rear cooling)

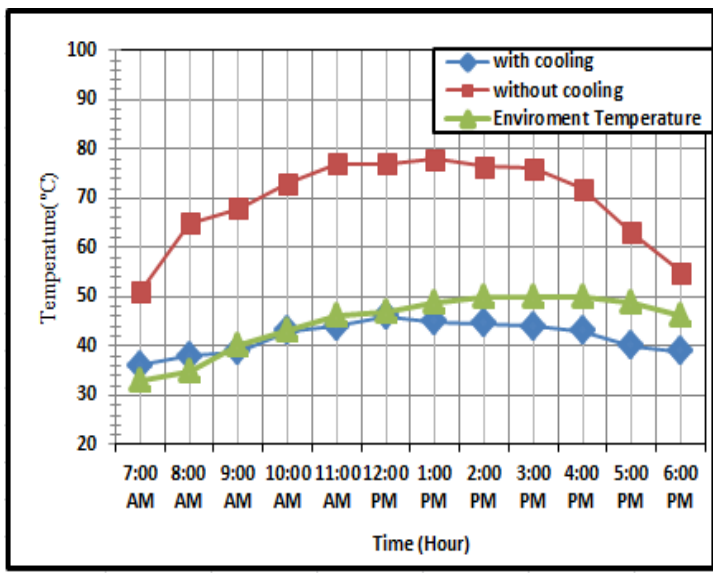

Figure (10):PV \& environment temp during daytime (rear cooling)

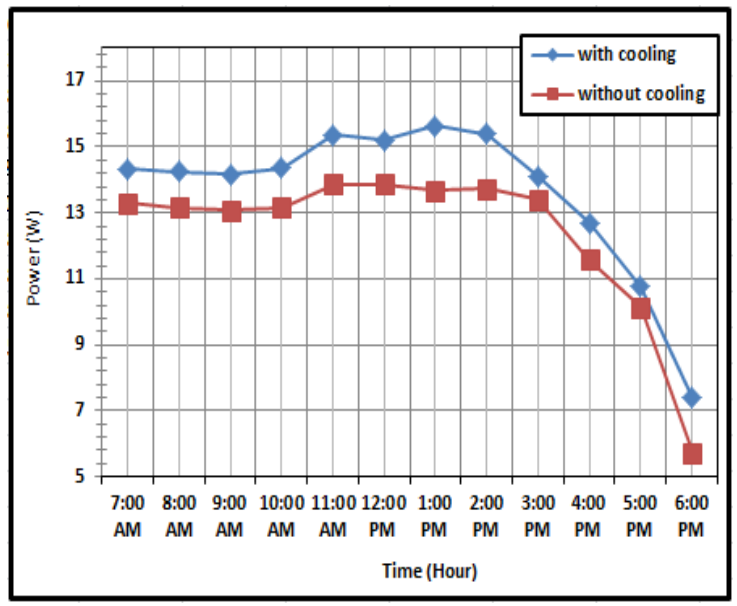

Figure (11): Maximum output power during daytime (rear cooling)

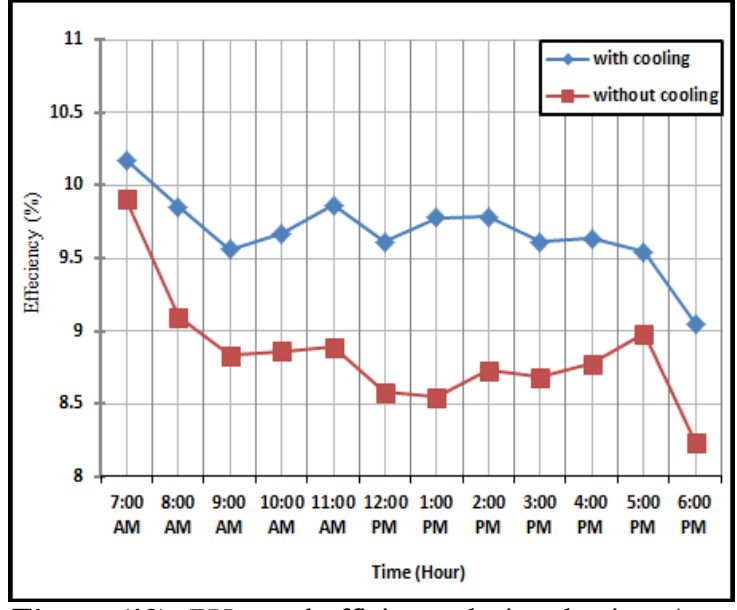

Figure (12): PV panel efficiency during daytime (rear cooling)

\subsection{Both cooling chambers:}

For both cooling chamber cases (front and rear), the PV panel will be cooled via both surfaces using the cooling chambers technique. The test was conducted with conditions that the irradiance is ranged between (326-889) $\mathrm{W} / \mathrm{m} 2$, environment temperature is between (37-49) oC, and the reference PV panel temperature (without cooling case) is ranging (55-78.8) $\mathrm{oC}$ as shown in Figs. 13 and 14. The average temperature reduction during daytime resulting from using double cooling techniques is about $50.06 \%$. This reduction will lead to more increment in the PV panel efficiency than other two previous cases.

The maximum power values of the cooled PV panel and reference one during the daytime shown in Fig. 15. The power values of the cooled PV panel is ranged between (16.23-4.63)W, while they are between (14.014.84)W for the reference panel. The maximum power increment when using cooling system is $16.62 \%$ with respect to the reference panel. The average increment is $12.69 \%$. The increment in the power during time interval of (8:00 AM -5:00 PM) is $12.88 \%$, while for the time interval (7:00 -8:00) AM and (5:00 -6:00) PM, the increment is about $3 \%$, this is due to the lower power gain caused by the lower irradiance and lower temperature difference between the two panel cases during these intervals. The electrical efficiency of the cooled panel increases maximally by $19.12 \%$ at $2: 00$ PM and averagely by $14.204 \%$ over the reference panel, as shown in Fig. 16. 


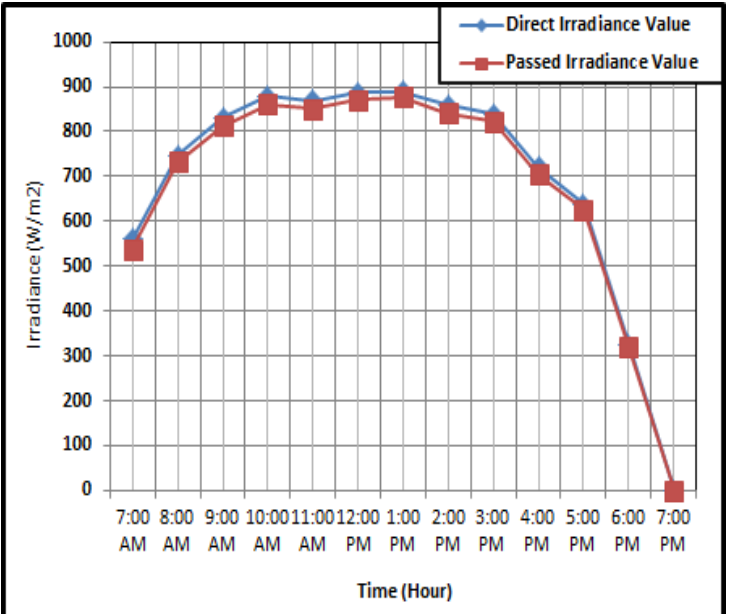

Figure (13): Solar irradiance during daytime (both front \& rear cooling)

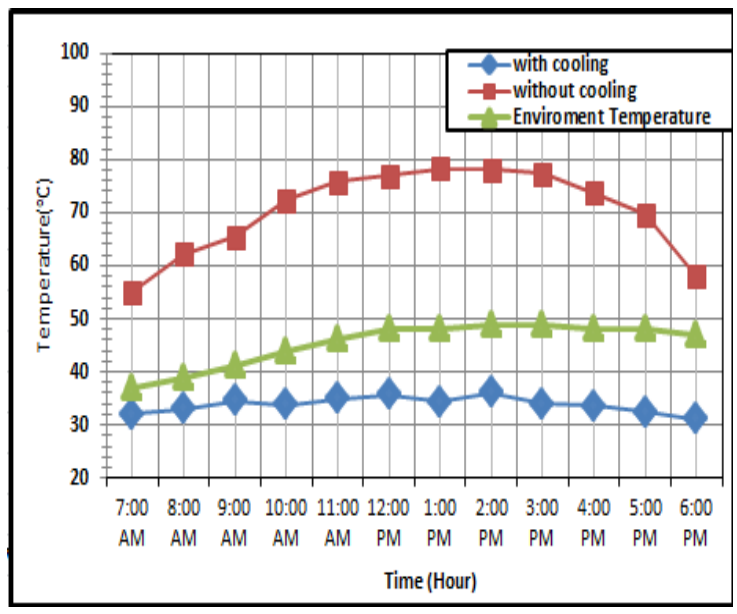

Figure (14): Panel temperature during daytime (both front \& rear cooling)

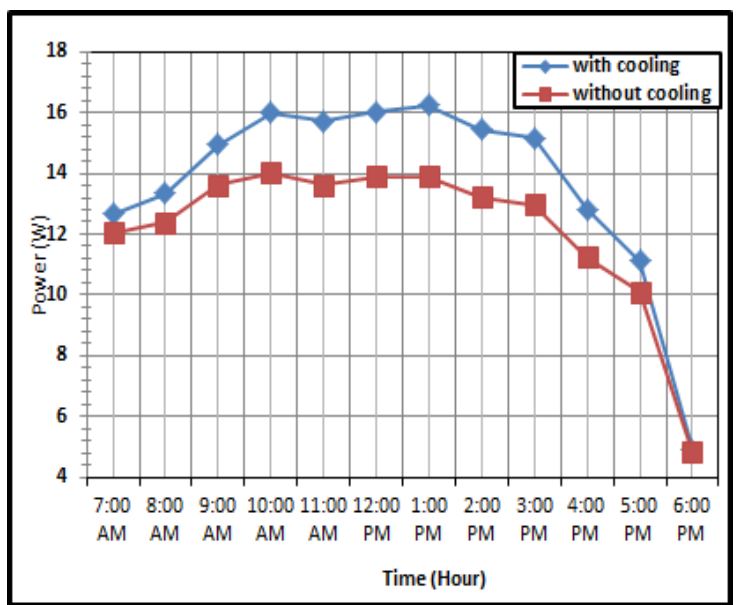

Figure (15): Maximum output power during daytime (both front \& rear cooling)

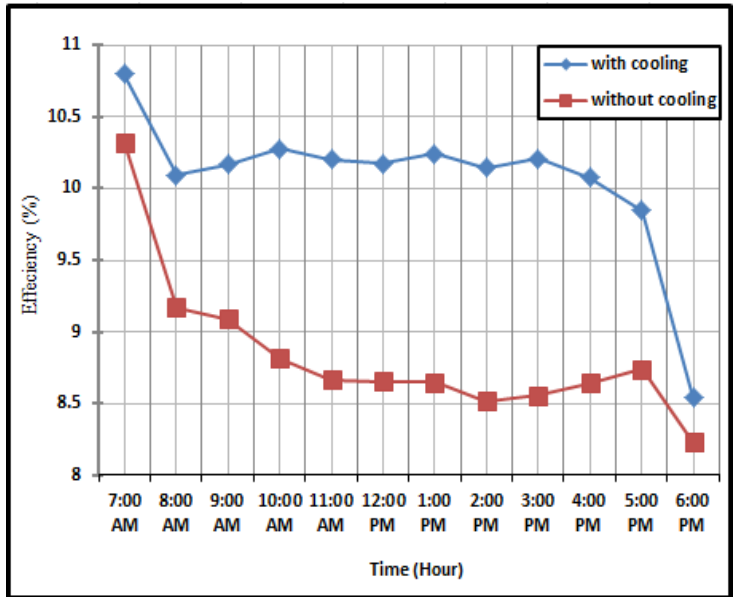

Figure (16): Panel efficiency during daytime (both front \& rear cooling)

\section{Conclusions:}

The present work investigates the Performance Enhancement of Photovoltaic Panel Using Doublesides Water Glazing Chambers Cooling Technique. The following concluding remarks could be drawn:

1. Using front water-cooling chamber executes; PV panel cooling and filtering the sun's irradiance as well as reducing its sunlight reflection falling on it.

2. The average reduction in the PV panel temperature is $45.56 \%, 40.12 \%$ and $50.06 \%$ with using (front, rear, and both sides) cooling chambers respectively.

3. With using the both sides cooling technique, the PV average electrical power and the electrical efficiency enhanced by $12.69 \%$ and $14.204 \%$ respectively.

\section{References}

[1] C. Zou, Q. Zhao, G. Zhang, B. Xiong, Energy revolution: From a fossil energy era to a new energy era, Natural Gas Industry B, Vol. 3, Issue 1, 2016, pp. $1-11$.

[2] Wim G. J. van Helden, Ronald J. Ch. van Zolingen, H.A. Zondag, "PV thermal systems: PV panels supplying renewable electricity and heat", Progress in Photovoltaic: Research and Applications, Vol. 12, pp. 415-426.

[3] Luque, Steven Hegedus, Chichester, Handbook of photovoltaic science and engineering, 2nd Edition, John Wiley \& Sons Ltd, United Kingdom, 2010.

[4] Radziemska. E, "The effect of temperature on the power drop in crystalline silicon solar cells", Renewable energy, Vol. 28, 2003, pp. 1-12.

[5] S. Dubey, J.N. Sarvaiya, B. Seshadri, "Temperature dependent photovoltaic (PV) efficiency and its effect on PV production in the world-a review", Energy Procedia, Vol. 33, 2013, pp. 311-321.

[6] S. Krauter, "Increased electrical yield via water flow over the front of photovoltaic panels", Solar energy materials and solar cells, Vol. 82, 2004, pp. 131 137.

[7] M. Abdolzadeh, M. Ameri, "Improving the effectiveness of a photovoltaic water pumping system by spraying water over the front of photovoltaic cells", Renewable Energy Vol. 34, 2009, pp. 91-96. 
[8] R. Hosseini, N. Hosseini, H. Khorasanizadeh, "An experimental study of combining a photovoltaic system with a heating system", World Renewable Energy Congress-Sweden, No. 057, Linköping University Electronic Press, 2011.

[9] H.G. Teo, P.S. Lee, M.N.A. Hawlader, "An active cooling system for photovoltaic modules", Applied Energy, Vol. 90, 2012, pp. 309-315.

[10] H. Bahaidarah, Abdul Subhan, P. Gandhidasan, S. Rehman, "Performance evaluation of a PV (photovoltaic) module by back surface water cooling for hot climatic conditions", Energy, Vol. 59, 2013, pp. 445-453.

[11] G. Colt, "Performance evaluation of a PV panel by rear surface water active cooling", Applied and Theoretical Electricity (ICATE), 2016 International Conference on. IEEE, 6-8 Oct. 2016.

[12] Rasha A. Nouri, "Efficiency Enhancement of Solar PV Panel Tracker Using Water-Flow Double
Glazing Technique", AL-Khawarizmi Engineering Journal, Vol. 14, 2018, pp. 32-47.

[13] T. M. Abu-Rahmeh, "Efficiency of Photovoltaic Modules Using Different Cooling Methods: A Comparative Study ", Journal of Power and Energy Engineering, Vol. 5, 2017, pp. 32-45.

[14] J. B. Satpute, J. A. Rajan "Recent Advancement in Cooling Technologies of Solar Photovoltaic(PV) System", FME Transactions, Vol. 46, 2018, pp. 575584.

[15] S. Ghoshal, S. Neogi, "Advance glazing systemenergy efficiency approach for buildings a review", Energy Procedia, Vol. 54, 2014, pp. 352-358.

[16] T. Chow, C. Li, Z. Lin, "Innovative solar windows for cooling-demand climate", Solar Energy Materials and Solar Cells, Vol. 94, 2010, pp. 212-220.

[17] J.P. Holman, Heat transfer, 10th Edition, McGraw-Hill, Inc, New York 2010.. 